\title{
Trafficking in Human Beings and International Peacekeeping Missions: The 2004 NATO THB Policy
}

\author{
Alvaro Ballesteros *
}

The time has come to tackle the slave trade once and for all, in the interest of not only the people most directly affected but the broader public as well. As usual when it comes to politics, Abraham Lincoln said it best: In giving freedom to the slave, we assure freedom to the free. Halt the global slave trade today, and all citizens of the world will benefit. Allow the practice to continue, and all will ultimately suffer.

Ethan Kapstein, “The New Global Slave Trade”1

The UN estimates that 2.5 million people are trafficked and enslaved, although the crime is frequently unreported and many estimates are far higher. The International Labor Organization estimates that there are 12.3 million people across the globe in forced work. The U.S. government says that up to 800,000 people are shipped like commodities across international borders to serve as cheap labor. About 50 percent of people smuggled and sold into forced work are minors and 80 percent are women and girls, according to a 2006 State Department study. Most end up working in the sex trade.

UN Fund to Combat Human Trafficking ${ }^{2}$

\section{Introduction}

"Trafficking in human beings (THB) flourishes throughout the world, aided by corruption, complicity, and neglect on the part of states around the globe.” ${ }^{3}$ This is a direct quotation, reference note number 3 below. The statement was produced at a press release. An essential activity in providing increased funding for organized crime groups around the globe, THB is essentially a form of modern-day slavery. Together with trafficking of drugs and weapons and smuggling of migrants, THB is one of the core activities of contemporary organized crime. Thus, it contributes to the flourishing of corruption, the consolidation of state failure, the development of links between organized crime and terrorism, and the exploitation and violation of human rights throughout the world.

* At the time of writing this article, Alvaro Ballesteros was the Executive Director of the European Academy for International Training (EAIT). He currently works for the OSCE. This essay is dedicated to his mentor, Col. James Howcroft, United States Marine Corps.

1 Ethan Kapstein, “The New Global Slave Trade,” Foreign Affairs 85:6 (Nov./Dec. 2006): 103-15.

2 UN Fund to Combat Human Trafficking, at www.humantrafficking.org; accessed 6 April 2007.

3 Statement by Martina Vanderberg, Europe Researcher, Women's Rights Division, Human Rights Watch, 24 April 2002. 
Since the 1990s, THB has become a considerable threat to international peacekeeping missions deployed under UN and NATO flags. Given peacekeepers' lack of proper training and failure to follow provided action guidelines, situations develop in peacekeeping missions that contribute to the violation of human rights, the activities of organized crime, and the failure to achieve mission goals. ${ }^{4}$ The press coverage linked to these cases also help to erode national support for peacekeeping operations, especially at a moment when the North Atlantic Alliance has 50,000 troops deployed in different missions around the world, and when public support for international operations is decreasing in various NATO countries. ${ }^{5}$

This essay aims at analyzing the efforts of the North Atlantic Treaty Organization to fight human trafficking, to prevent NATO personnel from becoming clients fueling the THB operations run by organized crime groups, and to implement the 2004 NATO Policy of "Zero Tolerance" regarding THB. In order to do so, this paper will try to present a clear definition of what the problem is, and to explain the repercussions and links between THB and international peacekeeping operations; the allegations and cases affecting the UN and NATO, with the consequent damage to both institutions' reputations; the development and content of the 2004 NATO Policy against THB; and the efforts to implement this policy. Finally, the essay will offer some recommendations for future steps.

In offering this analysis, I hope to support the North Atlantic Alliance's efforts to fight THB in a comprehensive and successful way, making NATO the example for institutionalized programmatic efforts against THB proliferation and troop-involvement prevention. This research also tries to provide an in-depth review of the 2004 NATO Policy against THB, including an evaluation of the policy implementation process from the approval of the policy in the summer of 2004 to the summer of 2007.

4 Canada in Kandahar: A Mission Assessment (Brussels: The Senlis Council, Security and Development Policy Group, June 2006); available at http://www.senliscouncil.net/modules/ publications/013_publication/exe_sum. "The resulting local negative perceptions of Canadian troops (in Afghanistan) seriously threaten Canada's reconstruction and developmentfocused mission. Incidents such as the unintentional killing of civilians are further dramatically decreasing popular support for the Canadian mission."

5 "Will Afghanistan receive the long-term support it needs? Western publics remain casualtyaverse and opposition parties in the Netherlands, Canada, and Britain have had success playing to these concerns. (...) While the American public typically supports operations in Afghanistan, rebuilding the country ranked dead last in a recent poll in which respondents were asked to rank the importance of 30 international concerns." Carl Robichaud, "Remember Afghanistan? A Glass Half Full, On The Titanic,” World Policy Journal 23:1 (Spring 2006); available at http://www.worldpolicy.org/journal/articles/wpj06-2/robichaud.html. "La OTAN está lidiando con fuertes presiones debido a su discutido liderazgo al frente de las tropas de ISAF. La opinión pública en su contra se incrementa en países como Gran Bretaña, Canadá e Italia.” Assol Borrego Batista, "La Guerra de Afganistán en el camino del fracaso,” CEAO (February 2007); available at www.ceao.cu/documentos/11.doc. 


\section{Definition of the Problem}

Human trafficking affects virtually every country in the world. The largest numbers of victims come from Asia, with over 225,000 victims each year from Southeast Asia and over 150,000 from South Asia. The former Soviet Union is now believed to be the largest new source of trafficking for prostitution and the sex industry, with over 100,000 women and children trafficked each year from that region. An additional 75,000 or more are trafficked from Eastern Europe. Over 100,000 victims per year come from Latin America and the Caribbean, and over 50,000 are from Africa. Most of the victims are sent to Asia, the Middle East, Western Europe, and North America. The U.S. Department of State has estimated that at any given time there are hundreds of thousands of people in the trafficking pipeline, being warehoused by traffickers, waiting for new routes to open up or documents to become available. Their primary destinations include the United States, the European Union, and Canada. ${ }^{6}$

For years, a variety of international organizations and institutions have struggled to provide a consolidated definition of what THB is. It was not until 2000 that the United Nations came up with a globally accepted description of the crime. The universal definition of the term Trafficking in Human Beings can be found in the Protocol to Prevent, Suppress and Punish Trafficking in Persons, especially Women and Children, supplementing the Convention against Transnational Organized Crime, that was adopted by the UN in Palermo, Italy, in 2000. It is one of the two Palermo Protocols, the other one being the Protocol against the Smuggling of Migrants by Land, Sea and Air. ${ }^{7}$

The trafficking protocol entered into force on 25 December 2003, and by July 2007 it had been signed by 117 states, and ratified by 113 states. ${ }^{8}$ These 113 ratifying states include 22 of the current 26 NATO allies and 20 of the 23 current member states participating in the NATO Partnership for Peace program. ${ }^{9}$

Article 3 of the UN Protocol to Prevent, Suppress and Punish Trafficking in Persons, especially Women and Children, defines trafficking in human beings as follows: ${ }^{10}$

For the purposes of this protocol:

6 American University Terrorism, Transnational Crime and Corruption Center (TraCCC) Web site, at www.american.edu/traccc/transcrime/humantraffic.html.

7 See Wikipedia entry at http://en.wikipedia.org/wiki/Protocol_to_Prevent\%2C_Suppress_ and_Punish_Trafficking_in_Persons\%2C_especially_Women_and_Children (accessed 10 July 2007).

8 UN Office on Drugs and Crime, Signatories to the UN Convention against Transnational Crime and its Protocols, at www.unodc.org/unodc/en/crime_cicp_signatures.html.

9 Luxembourg, Iceland, Greece, and the Czech Republic are the four NATO Allies that have not yet ratified the Trafficking Protocol, although the four states signed it in December 2000. Ireland and Uzbekistan are the two PfP member states that have not yet ratified the Protocol. Kazakhstan is the only PfP member state that has neither signed nor ratified the Protocol.

${ }^{10}$ See http://untreaty.un.org/English/TreatyEvent2003/Texts/treaty2E.pdf. 
(a) "Trafficking in persons" shall mean the recruitment, transportation, transfer, harbouring or receipt of persons, by means of the threat or use of force or other forms of coercion, of abduction, of fraud, of deception, of the abuse of power or of a position of vulnerability or of the giving or receiving of payments or benefits to achieve the consent of a person having control over another person, for the purpose of exploitation. Exploitation shall include, at a minimum, the exploitation of the prostitution of others or other forms of sexual exploitation, forced labor or services, slavery or practices similar to slavery, servitude or the removal of organs;

(b) The consent of a victim of trafficking in persons to the intended exploitation set forth in subparagraph (a) of this article shall be irrelevant where any of the means set forth in subparagraph (a) have been used;

(c) The recruitment, transportation, transfer, harbouring or receipt of a child for the purpose of exploitation shall be considered "trafficking in persons" even if this does not involve any of the means set forth in subparagraph (a) of this article;

(d) "Child" shall mean any person under eighteen years of age.

The Council of Europe (CoE), an international organization of forty-seven member states in the broad European region, adopted in May 2005 the Convention on Action against Trafficking in Human Beings. Its Article 4 defines THB with exactly the same wording as Article 3 of the UN Trafficking Protocol, adding a final clarifying subparagraph (e): “'Victim' shall mean any natural person who is subject to Trafficking in Human Beings as defined in this article." 11 Once a global definition was agreed upon in 2000, it became somewhat easier to make countries and international organizations understand the essence of the matter and the repercussions that it carries.

Trafficking in human beings is a global issue that represents an increasingly lucrative source of funding for organized crime networks, one that bears a low risk of detection and low penalties for the traffickers. This is especially relevant because-as has been already highlighted by many analysts - organized crime has direct links with terrorist groups. It is thus understood that the profits from exploiting people in the human trafficking industry go in part to fund the activities of terrorist networks, with all the attendant consequences. ${ }^{12}$

This has been especially apparent in regions like the Balkans, where the main UN and NATO international peacekeeping operations have been deployed since the

${ }^{11}$ Council of Europe CM (2005)32 Addendum 1 final, 925 Meeting, 3 and 4 May 2005, 4.5 Council of Europe Convention on Action against Trafficking in Human Beings.

12 "Human trafficking is a growing and serious form of organized crime. Far from being a homogeneous phenomenon, trafficking ranges from small networks to a highly organized trade by large crime groups that delivers individuals across continents. Human trafficking in some regions of the world links with the funding of terrorism in the intermingled world of the illicit economy.” Louise Shelley, Statement to the House Committee on International Relations, Subcommittee on International Terrorism, Nonproliferation and Human Rights, 25 June 2003; available at http://usinfo.state.gov/eap/Archive_Index/Human_Trafficking Transnational_Crime_and_Links_with_Terrorism.html. 
1990s. ${ }^{13}$ "Human trafficking is an issue of critical importance in South Eastern Europe not only because it infringes upon and challenges the protection of human rights, but also because it has the potential to undermine the process of democratization; discredit the rule of law; weaken efforts to reform and build institutions; promote corruption; and even to threaten the stabilization process in the region." ${ }^{14}$ The development of THB networks that are linked to issues such as widespread corruption and institutional malfunction constitute one of the main threats to the success of international peacekeeping operations, and also work to discredit the international organizations leading the peacekeeping efforts.

\section{Trafficking in Human Beings and Peacekeeping Operations}

"Boys will always be boys." This infamous statement-made in 1992 by the Head of the UN Transitional Authority in Cambodia, Yasushi Akashi, when commenting on allegations that UN peacekeepers were involved in cases of sexual abuse against local women - has been highlighted by different scholars and international speakers on various occasions as an example of an unacceptable official opinion being used to cover up for the misbehavior of UN personnel. This kind of perception regarding cases of sexual abuse by international troops has been shared by many observers for a long time. Some even agreed with another infamous quote, this one from Nazi Propaganda Minister Joseph Goebbels: "Men should be trained as warriors and women as recreation for the warriors. Anything else is foolishness." ${ }^{\prime 15}$

The history of sexual abuses perpetrated by armed forces is probably as old as humanity, with records of sexual violence being found in relation to almost every armed campaign and operation ever held. For a long time, these practices were considered normal wartime behaviors, and thus not much was done to prevent or punish them. In the modern era, though, the perception of the problem has gradually changed. This is a problem that has affected international peacekeeping missions set up under UN and NATO flags as well. However, the fact that the peacekeeping operations deployed since the beginning of the 1990s have been under stronger and more objective scrutiny has moved national governments and international organizations to pay a lot more attention in the recent past to issues like human trafficking and sexual abuses committed by members of peacekeeping missions.

13 “According to experts in the field, illegal trafficking in virtually any commodity and terrorism are linked in some parts of the world, as trafficking is a large and significant component of the illicit economy where these links with terrorism exist. These regions might include the Balkans, as well as parts of the former Soviet Union.” Lucia Ovidia Vreja, "Human Trafficking in South Eastern Europe,” Connections: The Quarterly Journal 4:4 (Winter 2005): 49-62.

14 Ibid., 50.

15 Vesna Kesic, “The Status of Rape as a War Crime in International Law: Changes introduced after the Wars in the Former Yugoslavia and Rwanda,” MA Thesis, New School University, December 2001. 
The two main international institutions that have organized and deployed international peacekeeping operations in the last twenty years are the United Nations and NATO. ${ }^{16}$ Hundreds of thousands of military, police, and civilian personnel have participated in all these different missions, which have been staffed by men and women who have served under their national colors and those of the umbrella organizations with the utmost professionalism, discipline, and honor. Many of them have lost their lives protecting and assisting refugees and victims of natural disasters, separating combatants, implementing ceasefires, and supporting stabilization and development programs run by different agencies. However, many of them have also engaged in criminal activities of various kinds. Human trafficking is one that has attracted special media attention in the last several years, thus eroding the credibility of the peacekeeping and institution-building efforts of both the UN and NATO.

It has been noted recently that, in regions of extreme conflict such as the Balkans, the presence of peacekeepers can often contribute significantly to the growth of trafficking networks and the embedding of organized crime within the community. The peacekeepers are a major revenue source for the brothel owners who keep the trafficked women. These revenues are used to neutralize law enforcement through corruption and to invest in the technology, intelligence gathering, and communications that are needed to expand the trade in trafficked humans. ${ }^{17}$

Having understood that human trafficking and sex abuse have been linked to peacekeeping operations for a long time, it is critical to analyze how they have most directly affected missions deployed under UN and NATO flags.

\section{Allegations Regarding UN Missions}

In relation to the UN, such acts as the ones described above cover a wide spectrum of behavior, from breaches of the organization's standards of conduct (such as solicitation of adult prostitutes, which may be legal in some countries) to acts that would be considered criminal in any national jurisdiction (e.g., rape and pedophilia). Besides the United Nations, media and human rights organizations in particular have documented the involvement of peacekeeping personnel in sexual exploitation and abuse in operations ranging from those in Bosnia and Herzegovina and Kosovo in the early 1990s to

16 The UN has deployed peacekeeping missions in Angola, Namibia, Mozambique, Somalia, Liberia, Rwanda, Uganda, Chad, Libya, Sierra Leone, Central African Republic, Burundi, Nicaragua, Guatemala, El Salvador, Honduras, Haiti, Afghanistan, Cambodia, Tajikistan, Timor-Leste, Bosnia and Herzegovina, Croatia, FYRO Macedonia, Iraq, Western Sahara, Sudan, Democratic Republic of Congo, Eritrea, Ethiopia, Ivory Coast, Cyprus, Georgia, Kosovo, and Lebanon. NATO has led peacekeeping operations in Bosnia and Herzegovina, Kosovo, FYRO Macedonia, and Afghanistan. 
Cambodia and Timor-Leste in the early and late 1990s to West Africa in 2002 and the Democratic Republic of Congo in 2004. ${ }^{18}$

Allegations of UN peacekeeping troops being involved in acts of sexual violence in general, and human trafficking in particular, are thus of fairly long standing. The different cases that provoked an increase in media coverage and global outrage motivated the UN to start working seriously in investigations of THB allegations. The worrying trend of official denial of any case in which UN staff seemed to be involved in THB activities started changing at the end of the 1990s. However, fierce critical voices and international monitors claim that, despite official recognition of the issue's gravity and public commitment from Secretary-General Kofi Annan to remedy the situation, little has changed on the ground since the UN adopted the already mentioned Protocol to Prevent, Suppress and Punish Trafficking in Persons, especially Women and Children in 2000, supplementing the Convention against Transnational Organized Crime.

"It is hard for the United Nations to take the lead in combating human trafficking when it is one of the major promoters of human trafficking in the world." 19 This statement was reportedly made in May 2007 by former U.S. Ambassador-at-Large on International Slavery John R. Miller to criticize the United Nations for promoting sex trafficking in peacekeeping missions, accusing the UN of failing to halt sexual abuse by UN peacekeepers.

The first reports of peacekeepers being involved in human trafficking were related to the UN peacekeeping and police missions in Bosnia and Herzegovina during and after the 1992-95 war. Personnel from some contingents of the UN Protection Force (UNPROFOR) were reportedly involved in cases of sexual abuse and human trafficking during the time of the armed conflict. ${ }^{20}$ The alleged involvement of personnel from the UN International Police Task Force (IPTF) and from the UN Mission in Bosnia and Herzegovina (UNMIBH) was also mentioned in specialized reports. ${ }^{21}$ It is relevant to highlight here the fact that the UN itself reportedly played an important role in substantially contributing to the lack of evidence in relation to the THB cases for which it had records in Bosnia and Herzegovina. When the UNMIBH closed down in December 2002, there was no reassignment of cases and files to the representatives of the newly launched EU Police Mission (EUPM) that was to replace UNMIBH on the

18 Comprehensive strategy to eliminate future sexual exploitation and abuse in United Nations peacekeeping operations, United Nations General Assembly, document A/59/710, 24 March 2005.

19 "Former U.S. Ambassador Criticizes UN for Promoting Sex Trafficking in Peacekeeping Missions,” Humantrafficking.org: A Web Resource for Combating Human Trafficking, News \& Updates (16 May 2007), at www.humantrafficking.org/updates/615.

20 Author's meeting with the Spanish writer and war reporter Juan Goytisolo in Sarajevo (B\&H), September 2000.

21 Human Rights Watch Report, Hopes Betrayed: Trafficking of Women and Girls to Post-Conflict Bosnia and Herzegovina for Forced Prostitution, Vol. 14, No. 9(D) (New York: Human Rights Watch, November 2002); available at http://www.hrw.org/reports/2002/bosnia/ Bosnia1102.pdf. 
ground. This resulted in a total lack of information and intelligence exchange between both missions in cases related to organized crime and THB. ${ }^{22}$

That same year the UN was again in the spotlight, taken aback by the news of widespread sexual exploitation and abuse by peacekeepers at a refugee camp in Western Africa. Responding to this case, Secretary-General Annan issued a bulletin in 2003 entitled "Special measures for protection from sexual exploitation and abuse." The bulletin forbade sexual activity with children under 18 years of age and with any other beneficiaries of assistance, and it prohibited the use of money, employment, goods, or services in exchange for sexual favors. The bulletin further instructed all department supervisors to report cases of human trafficking and sexual abuse by UN staff. ${ }^{23}$

Two years later, in 2004, the scandal of alleged widespread sexual abuse by UN troops deployed in Congo became public. As a response, Jordan's Ambassador to the UN, Prince Zeid al Hussein, was tasked to analyze the situation on the ground and present the General Assembly with a comprehensive review of the matter. Most of the allegations involved UN peacekeepers from Pakistan, Uruguay, Morocco, Tunisia, South Africa, and Nepal. Prince Zeid al Hussein's report on the alleged sexual abuses by UN peacekeepers in Congo was released in March 2005. He reportedly had discovered that peacekeepers had enticed desperate women and children to engage in sexual acts for a pittance of money or a small piece of food, sometimes giving them money or food after raping them to make the intercourse appear consensual. He stated that these crimes were widespread and ongoing. The Prince had reportedly also found evidence of peacekeeper obstruction of UN investigations into the crimes, paying or offering to pay witnesses to change their testimony, threatening investigators, and refusing to identify suspects. ${ }^{24}$ There have also been allegations of involvement of UN personnel in similar cases in Kosovo, with reports of UN DPKO acknowledging that "peacekeepers have come to be seen as part of the problem in trafficking rather than the solution."25

In May 2007, former U.S. Ambassador John R. Miller claimed that, despite the efforts and recommendations by Prince Zeid al Hussein in 2005, little had been done in the organization to prevent and punish similar cases. Currently a professor at Georgetown University, Miller's words were reportedly received with outrage by the UN Department of Peacekeeping Operations (DPKO) representative Yewande Odia, who claimed the world body is doing all it can, always depending on the individual commitment of each one of its member states.

22 "Experts in the region believe the UNMIBH was complicit in Human Trafficking." Sarah Mendelson, Barracks and Brothels: Peacekeeping and Human Trafficking in the Balkans (Washington, D.C.: CSIS, 2005).

23 U.S. Department of State, Trafficking in Persons Report, 5 June 2006; available at www.state.gov/g/tip/rls/tiprpt/2006/.

24 Keith J. Allred, "Peacekeepers and Prostitutes, How Deployed Forces Fuel the Demand for Trafficked Women and New Hope for Stopping It,” Armed Forces \& Society 33:1 (October 2006): 5-23.

25 Ian Traynor, “NATO force feeds Kosovo sex trade,” The Guardian (7 May 2004). 
The situation described above may be only the tip of the iceberg. With more than 68,000 UN peacekeeping troops deployed in more than seventeen missions abroad, it is hard to know how many similar cases have occurred or are actually ongoing. The latest reported scandal came to light in July 2007, involving the UN contingent of Moroccan troops deployed in Ivory Coast. The allegations of widespread sexual abuse are so serious that the UN has reportedly suspended the activities of the whole UN Moroccan battalion pending the results of the already initiated investigation of alleged sexual abuses involving peacekeepers and underage girls. ${ }^{26}$

This state of affairs is unacceptable to wide segments of the public. It shows once more that the issue of enforcing and maintaining discipline is critical if the credibility of the UN, the department of peacekeeping operations, and the future of the peacekeeping missions in general are to be preserved. The continuous problem the UN faces is that of the world body not having direct disciplinary authority over the peacekeeping troops, which are provided by the different member states. The contributing nations remain the sole authority with disciplinary jurisdiction over their own troops deployed in international operations, and in many reported cases no action is ever taken by the national authorities once sexual abuse cases are reported, or even after peacekeepers are repatriated. This situation jeopardizes the possibility of achieving successful prosecutions of the alleged traffickers and sexual predators, who are de facto protected by the blue beret of the United Nations. It also damages the public's perception of the UN and its international missions, with a growing number of taxpayers unwilling to see part of their taxes being used to contribute to activities that amount to gross human rights violations. ${ }^{27}$

26 “The United Nations is investigating allegations of widespread sexual abuse by hundreds of its peacekeepers serving in the Ivory Coast. A Moroccan battalion of 800 troops in Bouake, in the north of the country, were confined to their barracks on Friday and all of the contingent's activities suspended. The UN said an internal investigation 'revealed serious allegations of widespread sexual exploitation and abuse' by the unit which is serving in Bouake. The soldiers are alleged to have had sex with a large number of underage girls." "UN probes Ivory Coast Abuse,” Al Jazeera (21 July 2007); at http:/english.aljazeera.net/NR/exeres/ BC3F32AE-85FC-41D3-BC29-BB84C7D80510.htm.

27 “Con las Naciones Unidas aún bajo fuego por el mega-escándalo 'Petróleo por alimentos’ y otros actos de corrupción, denuncias de rampante explotación sexual y violación de chicas jóvenes y mujeres por parte de las así llamadas 'fuerzas de paz' de la ONU y civiles adjuntos en el Congo, están llevando su reputación global muy abajo.” ““Tropas de paz’ del Uruguay embarazan a 59 mujeres y niñas del Congo" (3 January 2005); available at http://uruguay.indymedia.org/news/2005/01/30405.php. 
Obviously, not all the measures announced by the UN have been implemented, and little has been learned from the events in Bosnia, Western Africa, Congo, Kosovo, and other missions. The latest allegations of widespread abuse in Ivory Coast prove that enforcing the existing disciplinary measures is the Achilles' heel of the United Nations' DPKO. The damage to the credibility of the organization on the world stage has been considerable.

\section{Allegations Regarding NATO Missions}

The North Atlantic Treaty Organization deployed its first NATO-led peacekeeping mission in December 1995 in Bosnia and Herzegovina in order to support the implementation of the Dayton peace accords. Other troop-deploying peacekeeping operations under the NATO flag followed in 1999 in Kosovo, and in 2001 in both FYRO Macedonia and in Afghanistan. ${ }^{28}$ All these different missions involved the deployment of large numbers of allied troops ${ }^{29}$ provided by NATO member nations, countries participating in the NATO Partnership for Peace (PfP) program, and other allied partner nations. ${ }^{30}$

"Desde entonces, son frecuentes los llamados a acabar con los brutales ataques de los cascos azules a esa comunidad, resarcir a las víctimas y contribuir al enjuiciamiento de los funcionarios, comandantes y soldados responsables de tales atropellos. También, las denuncias acerca de más de una treintena de casos de violaciones, pedofilia y tráfico humano con destino al comercio sexual, delitos que parecen formar parte del programa a cumplir por los policías y soldados de la ONU en ese territorio caribeño." "Las tropas de la ONU son cuestionadas en Haití,” La Republica (Madrid), (31 December 2006); available at www.larepublica.es/ article.php3?id_article=3420.

The NATO-led peacekeeping mission in Bosnia and Herzegovina (IFOR 1995-1996, SFOR 1996-2004) finalized after a 9-year-deployment, being replaced on the ground by EUFOR, the second EU-led peacekeeping operation. The NATO-led mission in Kosovo (KFOR) is still ongoing. The NATO-led deployment in FYRO Macedonia started right after the 2001 armed conflict (missions Task Force Harvest replaced by Task Force Fox) and concluded in March 2003 when the first ever EU-led peacekeeping operation (EUFOR CONCORDIA) took over. Finally, the NATO-led operation in Afghanistan (ISAF) is still ongoing.

IFOR deployed 54,000 troops under allied command in 1999, reducing the numbers under SFOR to 12,000 in 2002 and down to 7,000 in 2004, when the mission ended. KFOR deployed 50,000 allied troops in 1999, having reduced its numbers down to 17,000 in 2006. Operations Task Force Harvest and Task Force Fox deployed around 1000 servicemen and women (2001-03). ISAF consisted of about 35,500 personnel as of mid-2007. Herzegovina, Croatia, Finland, Georgia, Ireland, Kazakhstan, Kyrgyzstan, Moldova, Montenegro, Russia, Serbia, Sweden, Switzerland, Tajikistan, FYRO Macedonia, Turkmenistan, Ukraine, and Uzbekistan. The non-NATO, non-PfP partner nations that have contributed troops to NATO peacekeeping operations are Australia, New Zealand, Morocco, Argentina, Malaysia, India, Philippines, Mongolia, and the United Arab Emirates. 
Numerous allegations involving NATO peacekeeping troops ${ }^{31}$ and NATO civilian contractors $^{32}$ in cases of sex abuse and human trafficking have been reported in Bosnia and Herzegovina, as well as in Kosovo. ${ }^{33}$ NATO troops from different contingents serving in FYRO Macedonia under Task Force Fox (TFF) reportedly frequented bars where foreign women were forced to work as prostitutes. Sometimes the soldiers visiting these bars were clients of the sex workers, and sometimes the visits were part of an effort to identify trafficking bars in order to produce an accurate map of organized crime activities in certain parts of the country. ${ }^{34}$

It is clear, then, that human trafficking is a problem that affects international peacekeeping missions in general, including NATO. The threat to the credibility of the organization's humanitarian and peace building efforts is not to be underestimated.

\section{The 2004 NATO Policy against Trafficking in Human Beings}

The process of addressing the issue of THB within the North Atlantic Alliance and acknowledging the existence of the problem and the threat it poses to NATO has not been an easy one. Many senior NATO officials reportedly adopted an attitude of denial and failed to understand why human trafficking was a relevant matter for NATO. ${ }^{35}$

It was the decisive action of the ambassadors from the U.S. and Norway to NATO that reportedly pushed the alliance to take a solid stance to combat these cases and address the damage to NATO's credibility. Ambassadors Burns and Eide made NATO understand that "trafficking in persons in the Balkans undermines ongoing, significant

31 "Elena (a 20-year-old Moldovan victim of THB) says all sorts of customers patronized her bar, including locals, soldiers from the NATO-led Stabilization Force, SFOR, and even local policemen.” Nidzara Ahmetasevic, "Bosnia: Sex Slave Recounts Her Ordeal. Thousands of young women are still being held as sex slaves across the country despite the authorities' efforts to stamp out the trade," Institute for War and Peace Reporting, Sarajevo (18 March 2003); available at http://iwpr.gn.apc.org/?s=f\&o=157851\&apc_state=henibcr2003.

32 "Substantial evidence pointed to involvement by SFOR US civilian contractors, who had more freedom to move around Bosnia and Herzegovina than the SFOR peacekeepers and did not face the same prohibitions on visiting nightclubs.” Human Rights Watch, Hopes Betrayed, Chapter XI, 62.

33 "In a report on the rapid growth of sex-trafficking and forced prostitution rackets since NATO troops and UN administrators took over the Balkan province in 1999, Amnesty International said NATO soldiers, UN police, and western aid workers operated with near impunity in exploiting the victims of the sex traffickers. The report said that U.S., French, German and Italian soldiers were known to have been involved in the rackets." Traynor, "NATO force feeds Kosovo sex trade."

${ }^{34}$ Author's interviews with NATO TFF soldiers deployed in the Tetovo region, based in NATO Camp Erebino, during 2002 and 2003.

35 "Some senior civilian representatives of the DoD at NATO, as well as those who oversee peacekeeping for the secretary general of NATO, clearly did not understand why human trafficking should be addressed by NATO.” Mendelson, Barracks and Brothels, 60 . 
efforts to bring stability to Southeast Europe.”36 The result of the new Allied view of the problem was the drafting and endorsement of the June 2004 NATO Policy on Combating Trafficking in Human Beings (henceforth the Policy).

The Policy ${ }^{37}$ approaches the matter of human trafficking from a holistic and comprehensive perspective, having been drafted after a rigorous consultation process with international actors such as OSCE, the UN, international governmental and nongovernmental experts, PfP partners, NATO Mediterranean Dialogue countries, and troop-contributing nations involved in NATO-led operations.

The Policy:

- Defines human trafficking as a deeply destabilizing factor that runs counter to the NATO goals in South Eastern Europe

- Recognizes the UN Trafficking Protocol from 2000 as the framework document of reference, calling for the Allies and Partners to ratify it

- Recommends that THB pre-deployment training be provided to those who will participate in NATO-led operations

- Extends the anti-trafficking regulations to NATO troops and civilian contractors

- Calls on non-NATO troop-contributing nations to follow the Policy guidelines.

The Policy is complemented by Annex 1, entitled "NATO Guidelines on combating trafficking in human beings for military forces and civilian personnel deployed in NATO-led operations.” This document is divided into three sections: introduction and scope, general principles, and implementing guidelines.

The main points of this document are:

- Definition of the scope of the policy, including basic behavior standards for NATO-led forces, and parameters within which NATO missions can support the efforts of the host country

- Definition of general principles guiding the implementation of the Policy:

o NATO troops are forbidden to engage in THB activities

o NATO missions will support host nations' efforts

o NATO allies accept the UN Trafficking Protocol definition of THB

- Description of implementation guidelines:

o Establishing of NATO educational modules for raising awareness of THB

o Development of evaluation tools and internal control procedures

o Definition of points to be included in the planning of operations

o Operational plans to include anti-trafficking support measures

${ }^{36}$ Mendelson, Barracks and Brothels, 60; Keith J. Allred, "Human Trafficking: Breaking the Military Link,” Connections: The Quarterly Journal (Winter 2005), 68.

37 NATO PO(2004)0057, 27 May 2004, from Secretary General to Permanent Representatives (Council). 
o THB awareness training to be provided prior to deployment

o Assessment of conformity by NATO-led forces to measures

o Decision to have NATO operations link with victim protection institutions

o Requirement for allied nations to develop THB educational modules

o Requirement to ensure national legislation to punish those involved in THB activities

o Obligation for allied nations to report to NATO on national efforts

o Establishment of pre-deployment recommendations to troop-contributing nations:

- $\quad$ Pre-deployment training on THB matters and methods of countering it

- Timely investigation and prosecution of THB cases involving troops/ contractors according to standardized national legislation

- Development of mechanisms to report THB-related crimes

- Creation and dissemination of national policies protecting whistleblowers

- $\quad$ Creation of national databases with records of misconduct to be used in future recruitment, vetting, and deployment.

Annex 1 is likewise complemented by a document labeled Appendix 2: "NATO Guidance for the development of training and educational programs to support the policy on combating the trafficking in human beings.” This document recognizes the importance of training and raising awareness as key tools to ensure a successful implementation of the Policy. It also defines the two kinds of training to be offered by NATO and national training institutions:

- A general training module explaining what THB is and outlining the main legislative tools directed at punishing those involved in THB, with the following elements:

o Background explanation on THB, including its origins, victims, perpetrator's profile, and functioning dynamics of the crime

o Explanation of how THB is linked to other organized crime elements that threaten mission success

o Guidelines to detect victims and how to act when crime is detected

o Summary of relevant anti-trafficking legislation tools

- Specific modules designed for specific categories of personnel with specific responsibilities for policing the behavior of NATO-led personnel, including the following:

o Policy provisions for allied commanders on how to deal with cases involving subordinates

o Policy provisions for military police on how to investigate THB cases affecting NATO-led staff. 
Finally, Appendix 2 clarifies that, in order for such allied training effort to bear fruit, it should:

- Be provided to all levels of military and civilian staff

- Be tailored to specific audiences

- Include input from international anti-trafficking experts

- Focus on a train-the-trainers approach

- Include case studies and interactive learning methods

- Be adapted to distance and computer-based learning.

Annex 1 is further complemented by Appendix 3: "Guidelines for NATO staff on preventing the promotion and facilitation of trafficking in human beings." This document augments several of the points already mentioned in previous sections of the Policy:

- Prohibition against engaging in THB activities and obligation to report known cases involving NATO staff

- Recognition of the definition of THB as established in Article 3 of the UN Trafficking Protocol

- NATO staff includes everyone linked to a NATO operation, even consultants and temporary personnel

- Obligation for the allied nations to prosecute the troops involved in THB according to standardized national legislation.

A final NATO Policy, Annex AC/119-N(2004)0077, establishes the "Public Diplomacy Guidelines for the NATO Policy on Combating Trafficking in Human Beings." This document basically reminds the Allies that implementation is the key factor to making the Policy a success. It also provides states with a press kit to facilitate NATO specialized staff communication with the media in order to explain the Policy and its implications.

\section{Policy Analysis}

The Policy is without doubt the most comprehensive and best-structured institutional response to the crime of THB and the threat it poses to NATO-led peacekeeping operations. However, there are some gaps and issues that must be addressed by the Alliance in order to improve the Policy and to push its implementation farther.

As drafted and endorsed in 2004, the Policy has already had several positive effects:

- It has made the Allies understand that human trafficking is an important matter on the Alliance's agenda, and that prevention of this crime is essential to promoting the development of the rule of law, along with the stability- and institution-building processes needed in post-conflict territories. 
- It has encouraged the Allies and Partner nations to ratify the UN Trafficking Protocol and to adapt their national legislation to it. As a direct result, eight NATO Allies and nine PfP Partners have ratified the Protocol since the NATO THB Policy was adopted. $^{38}$

- It has made clear that NATO has a responsibility to police the actions of its troops and civilian contractors, whose actions have a direct effect on NATO's image in the host country.

- It has given THB a crucial place in the tactical, operational, and educational policies of the Alliance.

- It has rightly highlighted the fact that implementation is the key area of focus.

All these points mentioned above make the Policy a genuinely useful tool for setting the Alliance's agenda and providing key NATO officials with a clear understanding of the problematic nature of the issue and some hints as to the challenges ahead. However, the Policy has also several weak points when it comes to the most crucial issue-implementation.

The Policy establishes that NATO nations and Partner countries must:

- Adapt their legislation to the wording of the UN Protocol

- Provide THB pre-deployment training to all future mission staff to be sent to a NATO-led operation

- Support the host nation's anti-trafficking efforts

- Develop training modules and evaluation mechanisms

- Include THB-related measures in the operation plans

- Link with THB victim-support institutions in the host country

- Report to NATO regarding THB-related cases and developments

- Prosecute troops allegedly involved in THB activities according to their standardized national legislation.

This is a very ambitious package of measures. Nevertheless, many key questions are left unanswered by the Policy, such as:

- Who will evaluate the performance of NATO Allies and Partners in adapting their national legislation to the standardized goal?

- Who will produce the pre-deployment training materials?

- Who will evaluate that troops are receiving correct instruction?

38 The NATO Allies that ratified the UN Trafficking Protocol after the adoption of the NATO THB Policy are Belgium, Germany, Hungary, Italy, the Netherlands, Slovakia, the U.K., and the U.S. The PfP Partners that ratified the Protocol after the adoption the NATO THB Policy are Austria, Finland, Georgia, Montenegro, Moldova, Sweden, Switzerland, FYRO Macedonia, and Turkmenistan. 
- Who will assess the conformity of contributing forces to the principles articulated in the Policy?

- Who will receive the possible national reports on cases, disciplinary decisions, and follow-up events?

- Who will be the person/ unit/ institution in charge of liaising with host nation authorities, NGOs, and victim-support organizations?

- Who will collect the input from international THB experts and ensure the training materials are properly used?

- In general, who will be responsible for verifying that the Policy is finally implemented on the ground in a standardized manner?

The answers to these questions are crucial to efforts to strengthen the Policy. The fact that the Policy was approved in 2004 by NATO without designating an official authority to oversee its implementation called into question the Alliance's effort and commitment to deal comprehensively with the phenomena of THB and sex abuse by peacekeepers.

Another crucial weakness of the Policy as it was endorsed in 2004 is the fact that all issues related to the implementation of its provisions by the NATO member states depended on the voluntary commitment of the nations. No executive authority was vested in the Allied structures to compel the member states' governments to comply with the provisions of the Policy.

\section{Policy Implementation: 2004-2007}

Some analysts agree that, since the adoption of the Policy, progress is beginning to become apparent, and the initiative has led to many efforts on the part of the Alliance to tackle the problem of trafficking. ${ }^{39}$ However, three years since the date of the Policy's launch, the overall pace of implementation seems to be quite slow and hesitant.

In late 2004 and early 2005, NATO sponsored the creation of an ad hoc working group of international THB experts to design the training modules that were to be later

39 Keith J. Allred, “Analysis: Combating Human Trafficking,” NATO Review (Summer 2006); available at www.nato.int/docu/review/2006/issue2/english/analysis.html. 
used by the Alliance to raise troop awareness and provide pre-deployment training. ${ }^{40}$ The works of this expert group produced three anti-trafficking training modules that were supposed to be used by the Allied nations to specifically train all troops, troop commanders, and military police personnel. The modules were created in an on-line format in order to facilitate their use in training staff from the different member nation armed forces. However, it is unclear to what extent these materials are being used, by whom, and with what level of success.

One positive step was the incorporation (starting in 2005) of anti-trafficking lectures by the NATO School in Oberammergau (Germany) and the NATO Defense College in Rome into their curricula for both senior commanders and staff officers. Also, the NATO missions in the Balkans reportedly provide induction training for all personnel on a regular basis, ${ }^{41}$ and some of them, like the NATO mission in FYRO Macedonia, have engaged in organizing coordination meetings with all the different actors and institutions active in the anti-trafficking arena in the country. ${ }^{42}$ However, while NATO member states and Partners committed in 2004 to provide pre-deployment training for personnel participating in NATO-led operations, it is not clear that this commitment is really being fulfilled.

Another crucial step in the Policy's implementation has been the appointment in May 2007 of a NATO anti-trafficking coordinator, a post essential to harmonize the ef-

40 The expert working group was composed of independent experts and experts seconded from institutions and international missions such as the Geneva Centre for Security Policy (GCSP), the German Organization for Technical Cooperation (GTZ), the International Organization for Migration (IOM), the German Federal Ministry for Economic Cooperation and Development, the EU Police Mission to Bosnia and Herzegovina (EUPM), the EU Police Mission to FYRO Macedonia (EUPOL PROXIMA), the Romanian THB NGO Reaching Out, the Austrian National Defense Academy, the NATO Defense College, the UN Office of the High Commissioner for Human Rights (UNOHCHR), the UN Department for Peacekeeping Operations (UNDPKO) and the UN Office for Drugs and Crime (UNDOC), with the support of the Norwegian and U.S. Delegations to NATO. The author participated in the work of the NATO THB expert group the capacity of a representative of the EU Police Mission to FYRO Macedonia (EUPOL PROXIMA) during the working sessions held at the NATO School in Oberammergau in late February 2005.

41 U.S. Department of State, Trafficking in Persons Report, 5 June 2006; available at www.state.gov/g/tip/rls/tiprpt/2006/65992.htm.

42 The NATO mission in FYRO Macedonia and the EU Police Mission in the same country, EUPOL PROXIMA, developed a robust level of cooperation throughout 2005. The author provided (as EUPOL PROXIMA THB expert) awareness raising lectures for Allied staff in NATO Skopje HQ and in NATO Camp Able Sentry in August 2005, and participated in the NATO-sponsored coordination meeting held in Camp Able Sentry in November 2005. NATO representatives participated in the EUPOL PROXIMA THB Command Post Exercise held in Kavadarci (FYRO Macedonia) in October 2005 in order to develop the Macedonian police commanders' skills to organize a comprehensive operation against a fictitious regional THB mafia. Led by Italian State Police Lt. Col. Giorgio Butini, this was the first ever Command Post Exercise organized by an EU Police mission in the Balkans following European Police College (CEPOL) standards. 
forts of the different member and Partner states in order to achieve the realization of the Policy's provisions. The appointee is John Colston, NATO Assistant Secretary General for Defense Policy and Planning. He is the primary NATO point of contact for THB issues, being responsible for monitoring the implementation of the Policy. As such, he is expected to receive annual reports submitted by Allied and Partner countries and to report regularly to the North Atlantic Council and the Euro-Atlantic Partnership Council on the progress of the Policy's implementation. He is also expected to liaise with the relevant national authorities (as well as with international organizations and NGOs) to keep abreast of the latest developments in combating human trafficking, inform them about NATO's policy, and seek ways that NATO's work can be better coordinated with the activities of other international bodies. ${ }^{43}$

The appointment of the NATO THB coordinator is without question an essential step forward that many had judged necessary since the initial adoption of the Policy back in 2004. One complicating factor, however, is the fact that Allied and Partner nations are to submit annual reports to the coordinator only on a voluntary basis, since he has no executive power. This is somewhat problematic, as it does not address the key issue - the lack of political will within Allied and Partner nations to implement their obligations as established under the Policy.

\section{Conclusions and Recommendations}

In the view of the already mentioned recent THB and sex abuse scandals affecting peacekeeping operations around the world, it is clear that the implementation of the NATO Policy is crucial if the Alliance is to prevent possible new THB cases and the threats to mission success that such cases carry. The implementation of the Policy seems to still be at an early stage, with relevant but somewhat dilatory initiatives that seem to lack muscle. The pace of Policy implementation will be decisive to ensuring the credibility of the Alliance's efforts.

NATO must press ahead with the necessary Policy-related reforms, and should further encourage the opening of deeper national debates to seriously address the roots, causes, and issues that explain the involvement of peacekeepers in THB and sex abuse activities. There is still a lot of work ahead in order to develop comprehensive national strategies and doctrines that would prevent peacekeepers from engaging in criminal activities of this nature. What is clear is that - rather than avoiding a serious, deep debate on the subject—it must be recognized that soldiers have sexual needs that must be addressed. This debate must include considerations from different perspectives, dealing with matters related to leadership and command issues, personal responsibility, home leave policies, ethical principles, education, and rigorous pre-deployment selection and training.

Finally, it is important to reinforce the message that the Policy has correctly identified many of the key points that must be addressed in order to fight and prevent cases

43 NATO News, “NATO’s anti-trafficking coordinator explains priorities," 9 May 2007; available at www.nato.int/docu/update/2007/05-may/e0509b.html. 
of THB affecting Allied and Partner countries' troops. As repeated several times above, it is the implementation of these provisions that will bring the Alliance the results it expects.

Some further recommendations that may help in developing the work already done and that may prove crucial are given below, both for the NATO THB coordinator and for the NATO member states in general.

For the newly appointed NATO THB coordinator:

1.Dispatch independent THB expert teams to tour the Allied countries and field missions in order to assess the level of compliance with the Policy's provisions on the ground. The independent THB expert teams should report solely to the NATO THB coordinator. This is the only way to ensure that their assessment is objective and accurate. This will prove crucial in order to produce a road map to design future implementation steps based on a realistic assessment of the situation.

2. Develop a holistic NATO anti-trafficking strategy that focuses on prevention instead of on consequence management.

3. Assume a proactive role in order to standardize policy implementation mechanisms among Allies.

For the Allied nations:

1.Ensure that the NATO THB coordinator receives all necessary support. This implies that the states will implement the Policy's provisions and accept the coordinator's guidance to standardize policy implementation mechanisms among Allies.

2. Report to the coordinator's office on any THB issue/case that may be relevant and useful for the other Allies in order to strengthen the lessons-learned mechanism.

3. Ensure that the training modules developed by NATO are used in order to provide comprehensive training to national troops. Report any comments on the validity/ problems/usefulness of the modules to the coordinator's office.

4. Ensure that THB cases are properly dealt with, that troops allegedly involved are prosecuted upon repatriation, and that victims are supported/compensated accordingly. 


\section{THE QUARTERLY JOURNAL}

\section{Bibliography}

Ahmetasevic, Nidzara. Bosnia: Sex Slave Recounts Her Ordeal. Thousands of young women are still being held as sex slaves across the country despite the authorities' efforts to stamp out the trade. Sarajevo: Institute for War and Peace Reporting, 2003.

Allred, Keith J.. "Analysis: Combating Human Trafficking." NATO Review (2006).

Allred, Keith J.. "Human Trafficking: Breaking the Military Link." Connections: The Quarterly Journal 4, no. 4 (2005): 63-72.

Allred, Keith J.. "Peacekeepers and Prostitutes, How Deployed Forces Fuel the Demand for Trafficked Women and New Hope for Stopping It." Armed Forces \& Society 33, no. 1 (2006): 5-23.

Batista, Assol Borrego. La Guerra de Afganistán en el camino del fracaso. CEAO, 2007.

Canada in Kandahar: A Mission Assessment. Brussels: The Senlis Council, Security and Development Policy Group, 2006.

Comprehensive strategy to eliminate future sexual exploitation and abuse in United Nations peacekeeping operations. United Nations General Assembly, 2005.

Council of Europe Convention on Action against Trafficking in Human Beings In Council of Europe., 2005.

Former U.S. Ambassador Criticizes UN for Promoting Sex Trafficking in Peacekeeping Missions. Humantrafficking.org: A Web Resource for Combating Human Trafficking, News \& Updates, 2007.

From Secretary General to Permanent Representatives., 2004.

Hopes Betrayed: Trafficking of Women and Girls to Post-Conflict Bosnia and Herzegovina for Forced Prostitution. Human Rights Watch Reports 14, no. 9 (2002).

Kapstein, Ethan. "The New Global Slave Trade." Foreign Affairs 85, no. 6 (2006): 103-15.

Kesic, Vesna. The Status of Rape as a War Crime in International Law: Changes introduced after the Wars in the Former Yugoslavia and Rwanda In New School University. Vol. MA Thesis. Subcommittee on International Terrorism, Nonproliferation and Human Rights, 2001.

Las tropas de la ONU son cuestionadas en Haití. La Republica (Madrid) (2006).

Mendelson, Sarah. Barracks and Brothels: Peacekeeping and Human Trafficking in the Balkans. Washington, D.C.: CSIS, 2005. 
NATO's anti-trafficking coordinator explains priorities. NATO News, 2007.

Robichaud, Carl. "Remember Afghanistan? A Glass Half Full, On The Titanic." World Policy Journal 23, no. 1 (2006).

Shelley, Louise. Statement to the House Committee on International Relations, Subcommittee on International Terrorism, Nonproliferation and Human Rights., 2003.

Statement by Martina Vanderberg. Europe Researcher, Women's Rights Division, Human Rights Watch, 2002.

Trafficking in Persons Report 2006. U.S. Department of State, 2006.

Traynor, Ian. "NATO force feeds Kosovo sex trade." The Guardian (2004).

UN Fund to Combat Human Trafficking., 2007.

Vreja, Lucia Ovidia. "Human Trafficking in South Eastern Europe." Connections: The Quarterly Journal 4, no. 4 (2005): 49-62. 